\title{
Productivity and costs of harvester cutting of teak trees for thinning
}

\author{
Fidel Cándano Acosta ${ }^{1}$ (D) \\ Igor Martins Silva ${ }^{1}$ \\ Marcos Leandro Garcia ${ }^{2}$ (D) \\ Rafael Rodolfo de Melo $^{3}$ (D)
}

\begin{abstract}
This work was carried out in a teak plantation in the state of Mato Grosso, Brazil. The objective was to evaluate technical and economic indicators of the cutting and processing of trees with a track harvester. Twenty complete work shifts were evaluated using direct thinning to determine operational cycle times. Other information was also recorded for the calculation of production costs. The second thinning was performed at 12 years, with a volume of $0.1648 \mathrm{~m}^{3} /$ tree, and the third thinning at 18 years with $0.3408 \mathrm{~m}^{3} /$ tree. The main finding was an increase in productivity and decrease in production costs with rising tree volumes. For each hour of effective work, 53 trees were cut (339 trees/day), and processed into 1,047 logs. The decrease in the cost of cutting and processing trees in proportion to the increase in the average volume of trees to be extracted was confirmed.
\end{abstract}

Keywords: Forest machines, mechanized cutting of trees, cut-to-length system.

\section{INTRODUCTION}

Teak plantations in Brazil are located mainly in the states of Mato Grosso, Pará and Rondônia, occupying an area of approximately 80 thousand hectares. The leading state is Mato Grosso, with 70 thousand hectares distributed in several municipalities, especially Cáceres, Quatro Marcos, Porto Espiridião, Tangará da Serra and Alta Floresta. The species has been planted in these states due to the good soil and climate conditions in relation to other regions of Brazil and the world, as well as the high value of the wood (Takizawa, 2018). Simultaneously, tree cutting and processing operations have intensified, reflecting the acquisition of machines capable of meeting demand. In this respect, many companies have purchased harvesters to do work formerly carried out with chainsaws.

An alternative for tree harvesting is the use of tracked tractors equipped with processor heads. This is an attractive option mainly due to the low acquisition cost and the existence of models manufactured in the country, facilitating technical assistance and purchase of spare parts (Seixas \& Batista, 2014). According to those authors, tracked harvester models have lower operational cost than wheeled models on flat terrain, and the productivity results are similar. Spencer (1992) and Johansson (1995) previously published similar results.

Bezerra et al. (2011), studying several scenarios of the production of teak from seeds in regions of the state of Mato Grosso, found that due to slow tree growth and high production costs, it was not possible to achieve economic viability of teak production. The performance of the machines used has a strong influence on the production economics.

The effect of the land slope on the harvester performance has also been studied by several authors. In some cases, there were productivity losses of up to $38 \%$ and cost increases of up to $200 \%$. The maximum harvesting complexity occurs in areas with steep inclination and clayey soils in the wet state, including greater risk of accidents (Tolosana et al., 2002; Lopes et al., 2007; Simões et al., 2010; Fernandes et al., 2013; Silva et al., 2014; Ackerman et al., 2018).

\footnotetext{
${ }^{1}$ Universidade Federal de Mato Grosso, Instituto de Ciências Agrárias e Ambientais, Sinop, MT, Brasil.

${ }^{2}$ Universidade do Estado de Mato Grosso, Alta Floresta, MT, Brasil.

${ }^{3}$ Universidade Federal Rural do Semi-Árido, Departamento de Ciências Agronômicas e Florestais, Mossoró, RN, Brasil.
} 
The type of assortment also influences the productivity of tree processing. The operation of removing the bark and dismantling the tree consumes approximately $60 \%$ of the time in the harvester's operational cycle. The processing time is also greater to produce shorter logs (Silva et al., 2010). Hildt et al. (2018) found an increase in chopping time of up to $21 \%$ when the number of cuts per tree increased.

The selective cutting of thin trees forces the machine operator to take greater care to identify and cut and process the indicated trees in comparison with clear cutting, so as to avoid damage to remaining trees. This is corroborated by the results published by Kärhä et al. (2004), Mederski (2006) and Hildt et al. (2018), showing a decrease in the productivity of cutting and processing, and an increase in the cost of production compared to clearcutting.

The harvester operator's experience is another important factor of operational performance. According to Leonello et al. (2012) when evaluating a group of operators between 23 and 46 years of age, there was a large increase in operational performance in the first 18 months of experience, and it continued to rise in the next 26 months, while after 44 months the yields tended to decline or remain at the same level. This finding suggests that approximately 50 months of work is needed to recycle the operators' training to enable further growth of their skills. In this same sense, Purfürst and Erler (2011) conducted an investigation with 32 operators over a period of three years and concluded that the average volume of trees and the machine operator explained $84 \%$ of the general variation in productivity. The operator only explained $37.3 \%$ of the difference in productivity when working with the harvester.

Several studies have been published in Brazil on the mechanized operation to cut and process trees in plantations of Eucalyptus spp. However, there are no data on the performance of machines for the selective cutting for thinning of teak trees that allow proper planning of activities. Hence, the objective of this study was to investigate the influence of volume of the trees on the productivity of mechanized cutting and processing.

\section{MATERIAL AND METHODS}

\subsection{Location and characterization of the study area}

The study was conducted in a teak plantation in the state of Mato Grosso, located in the Midwest region of Brazil, at coordinates $10^{\circ} 03^{\prime} 10^{\prime \prime} \mathrm{S}$ and $56^{\circ} 49^{\prime} 32^{\prime \prime} \mathrm{W}$. The climate of the region has two well-defined seasons, with rainy summer from December to March and dry winter from June to September, and average annual temperature of $25.4^{\circ} \mathrm{C}$. The average annual rainfall recorded in the region is $2,281 \mathrm{~mm}$. The terrain is undulating with slopes that do not exceed $15 \%$. The soil is clayey with good drainage. The initial planting arrangement was $4 \times 2$, with 1,250 trees per hectare. The seedlings were produced by the company from seeds obtained in Mato Grosso.

In the first thinning, the intensity was $40 \%$ at the age of 6 years, when 500 trees were extracted with a volume of $31.25 \mathrm{~m}^{3} /$ ha, using a chainsaw for cutting and processing the trees. The second thinning was at the age of 12 years, with intensity of $40 \%$, and the volume extracted was $49.44 \mathrm{~m}^{3} / \mathrm{h}$. The third thinning occurred at the age of 18 years, with intensity of $45 \%$ and harvested volume of $68.84 \mathrm{~m}^{3} / \mathrm{ha}$. In the last two cases, the thinning was performed with a harvester.

The intensity of each thinning was based on the number of trees allowing maintaining competition among them and guaranteeing the greatest increase according to results determined in the region. The selection of the trees to be extracted in each thinning followed two main criteria: (i) selective, to eliminate trees with stunted growth, trunk defects, deformed or irregular crowns and/or presence of pests, considering that the final objective is to obtain logs of high commercial value; and (ii) systematic, to maintain the spatial distribution of the trees throughout the planted area.

\subsection{Harvest system, description of the process and characteristics of the machine}

The harvesting system used was cut-to-length, with the sequence of felling, disassembly, cutting, trimming the trunk and stacking the logs with the harvester. The machine moved between two rows by cutting the previously selected trees covering two rows of trees on each side. The logs were stacked and prepared for transport, as observed in Figure 1.

The base machine is composed of a Caterpillar tracked tractor, model 315D, $86 \mathrm{~kW}$ engine power, equipped with an articulated arm with horizontal reach of $8 \mathrm{~m}$ and a Log Max head, model 5000, with maximum roller opening $519 \mathrm{~mm}$, feed speed $4.1 \mathrm{~m} / \mathrm{s}$ and maximum cutting capacity of $630 \mathrm{~mm}$. The operational weight of the machine is $17280 \mathrm{~kg}$. The machine operator had more than five years of experience performing the operation. 


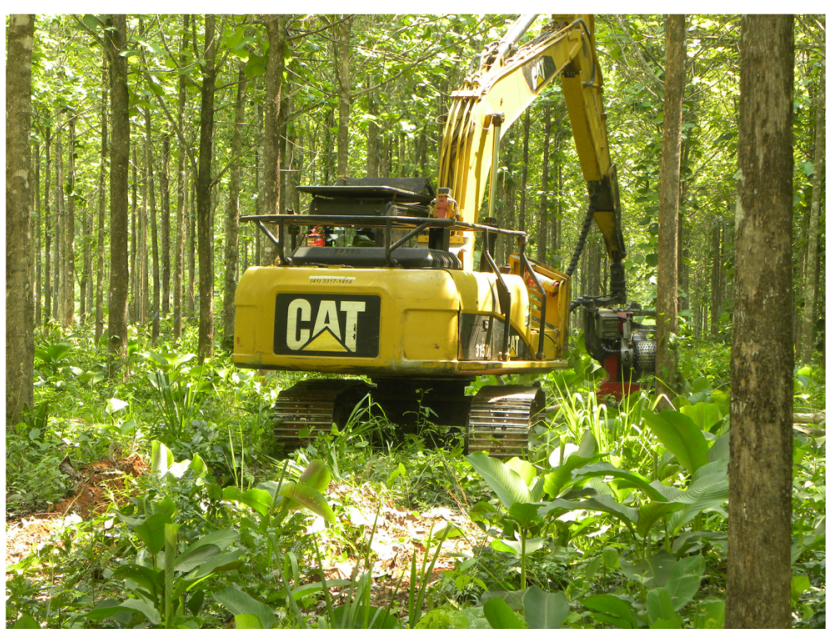

Figure 1. Harvester cutting and processing in teak plantation.

\subsection{Data collection and processing}

For the collection of data, the total time of the working day was divided into effective time and interruption time. The first included moving time (movement by the machine from one tree to another and clearing of undergrowth); felling time (positioning the head on the trunk, making the cut and toppling the tree); and processing time (delimbing, bucking and sorting of logs).

The interruption time was divided into mechanical (general review of the machine, light repairs, fueling, cutting system adjustments); operational (cleaning the machine with dry leaves and branches, receiving instructions from the manager, unfavorable weather conditions) and personal (satisfying basic operator needs).

Each tree cut and processed was considered an operational cycle. Twenty working days were evaluated between the months of June and August 2018. In each cycle, each of the mentioned times was recorded continuously using two stopwatches. Interruption times did not occur in all cycles. Subsequently, the sample size was calculated using the expression proposed by Barnes (1968).

Through pre-sampling, the minimum number of operational cycles was estimated for an allowable sampling error set at $5 \%$ and $95 \%$ probability level (Equation 1).

$$
n \geq \frac{t^{2} \times C V^{2}}{E^{2}}
$$

Where:

$\mathrm{n}=$ Minimum number of operational cycles required;

$\mathrm{t}=$ Student $\mathrm{t}$-value, at the desired probability level and (n-1) degrees of freedom; $\mathrm{CV}=$ Coefficient of variation $(\%)$;

$\mathrm{E}=$ Permissible error (\%).

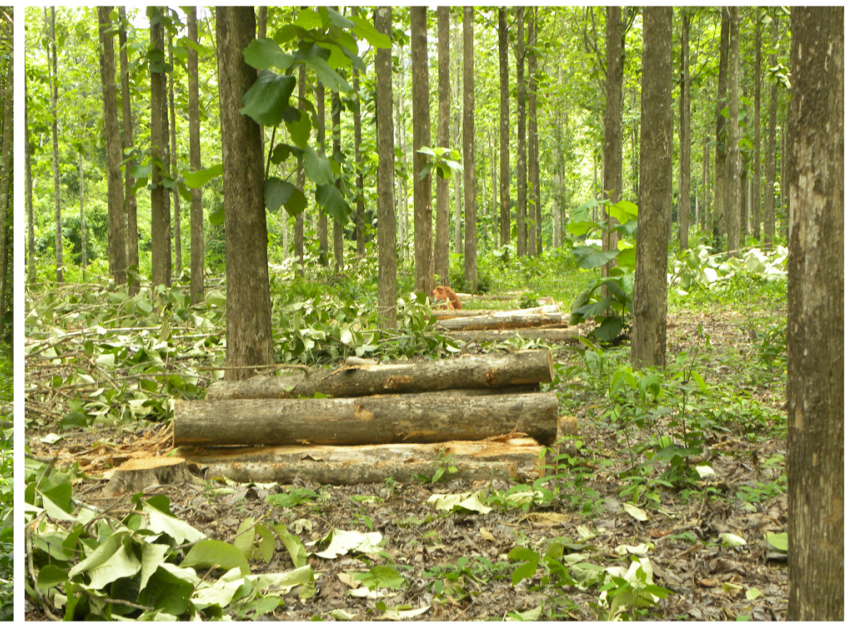

\subsection{Calculation of technical indicators of cutting and processing with harvester}

The equations for the calculation of technical indicators are presented below (Equation 2 - mechanical availability; Equation 3 - operational efficiency; Equation 4 - effective productivity).

$$
\begin{gathered}
M A=\frac{W T-I T}{W T}{ }^{*} 100 \\
E o p=\frac{T e f}{T e f+T i} \star 100 \\
P e f .=\frac{V c}{T e f}
\end{gathered}
$$

Where:

MA = Mechanical availability (\%);

$\mathrm{WT}=$ Total work time per day $(\mathrm{h})$;

IT = Interruption time for repair and maintenance $(\mathrm{h})$;

EOp = Operational efficiency (\%);

Tef $=$ Effective working time $(h)$;

$\mathrm{Ti}=$ Time of operational interruptions $(\mathrm{h}) ;$

Pef = Effective productivity $\left(\mathrm{m}^{3} / \mathrm{h}\right)$;

$\mathrm{Vol}=$ Volume produced $\left(\mathrm{m}^{3}\right)$; and

Regression analysis was performed using as independent variable the average volume of trees to estimate the effective productivity of the operation. Transformations of the model variables were performed. For the adjustment and selection of the model, the coefficient of determination $\left(\mathrm{R}^{2}\right)$, standard percentage error (Syx\%) and graphical analysis of residuals were used. A total of 483 work cycles were randomly selected 
to calculate the sample size. The work cycle number was defined according to the calculation of a pilot study, based on the coefficient of variation, for an error of 5\% and 95\% probability level.

The commercial volume produced in each cycle was recorded and stored in the computer installed in the machine's control cabin and extracted at the end of each day. Other data, such as the wages of the operators and acquisition cost of the machine, among others, were provided by the plantation owner. The method recommended by Sessions and Sessions (1992) was used to calculate the machine's operating cost and production cost.

The general formulas are: Equation 5 - operational cost of the machine; Equation 6 - cost of production.

$$
\begin{aligned}
& C o p=\text {. Copf }+C o p v+C o p m \\
& C p=\frac{C o p .}{P e f}
\end{aligned}
$$

Where:

Cop. $=$ Operational cost of the machine (US\$ $/ \mathrm{h})$;

Copf $=$ Fixed cost $(\mathrm{US} \$ / \mathrm{h})$;

Copv $=$ Variable cost $(\mathrm{US} \$ / \mathrm{h})$;

Copm $=$ Labor cost $(\mathrm{US} \$ / \mathrm{h})$

$\mathrm{Cp}=$ Cost of production $\left(\mathrm{US} \$ / \mathrm{m}^{3}\right)$.

\section{RESULTS}

\subsection{Time analysis of cutting and processing harvested trees}

During the 20 workdays, we observed an effective operating time of $71.2 \%$ and interruption time $28.8 \%$ in 9 hours of work. The actual time consumed more than $60 \%$ of the process, as shown in Figure 2. During the process, it was necessary to carry out three operations: felling, which was difficult because the trees had heavy branches in many cases due to the lack of appropriate treatment; removing branches and cutting trunks into logs; and stacking the logs for later collection.

The cutting consumed slightly more than $30 \%$ the time, including gripping the trunk in the machine head, cutting the tree and processing it into logs. Although the trees were young, most had irregularities at the base of the trunk where the cut was made, and the operator had to find the most favorable position. The movement of the machine between trees constituted $3.6 \%$ of the effective time. For each hour of effective work, 53 trees were felled and processed on average, and in the work shift, 339 trees were felled and cut into 1,047 logs (approximately three logs per tree).
The mechanical interruptions of the machine represented $60 \%$, including breakdown and repair, sharpening of the cutting chain, and fuel supply. Operational interruptions accounted for $22.2 \%$, especially for stops to clean branches and leaves that fell near the tractor's engine (which can cause fires). The interruptions related to the operator were minor, caused by physiological needs. This distribution provided mechanical availability of the machine of $82.7 \%$, operational efficiency of $71.1 \%$ and average effective productivity of $10.8 \mathrm{~m}^{3} / \mathrm{h}$.
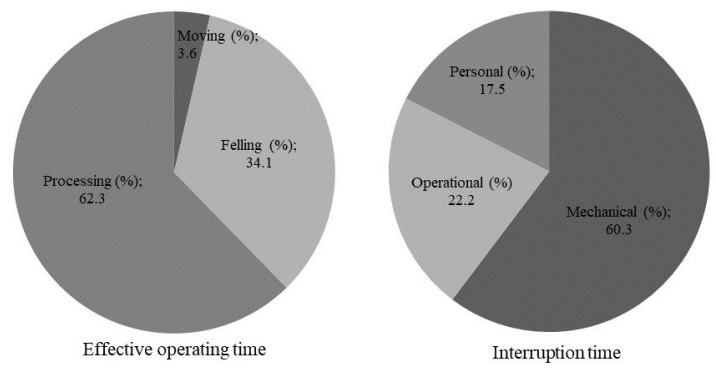

Figure 2. Distribution of working time in the cutting and processing of trees.

\subsection{Statistical model to estimate productivity vin cutting and processing trees}

To determine the required sample size, 483 operational cycles were used. According to the calculation of the pilot study, it was necessary to cut and process 259 trees or cycles, with a coefficient of variation of $36 \%$, for an error of 5\% and $95 \%$ probability level. Through the regression analysis, a linear statistical model was obtained that was able to estimate the productivity values based on the size of the trees with a coefficient of determination of 0.76 .

As can be seen in Figure 3, the volume of trees had a strong influence on the cutting and processing productivity, showing values of approximately $6.0 \mathrm{~m}^{3} / \mathrm{h}$ for trees with volume of $0.15 \mathrm{~m}^{3}$, while for trees with volume of $0.35 \mathrm{~m}^{3}$, productivity reached values greater than $14.0 \mathrm{~m}^{3} / \mathrm{h}$. This trend is explained because to cut and process a cubic meter of small trees, the machine has to move and perform operations more often than for large trees. For trees with a volume of $0.20 \mathrm{~m}^{3}$, it was necessary to locate, move, cut down and process five trees, while with trees having volume of $0.35 \mathrm{~m}^{3}$ it was only necessary to perform these operations on three trees to produce a cubic meter.

The productivity values in addition to increasing with the size of the trees, also showed dispersion, which occurred because in trees with greater diameter, the deformation at the base of the tree is greater, making it more difficult to place 
the harvester head in the most favorable position to secure the bottom of the tree and make the cut.

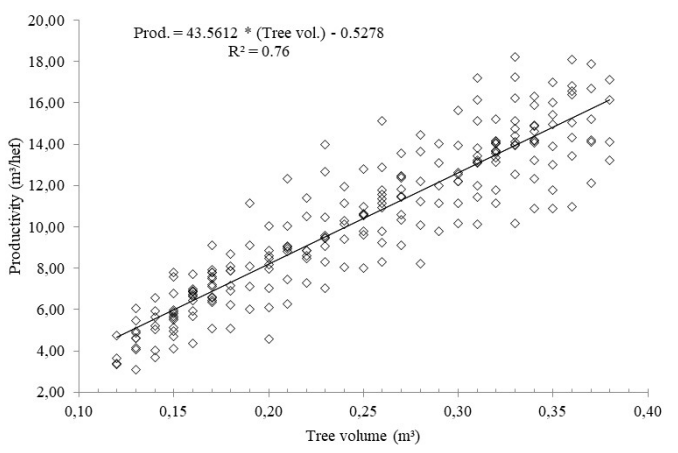

Figure 3. Effective productivity according to the volume of trees.

\subsection{Operational cost of the harvester for the cutting and processing of trees}

The total operational cost of the machine was US $\$ 80.66 / \mathrm{h}$, $30.7 \%$ allocated to fixed costs and $69.3 \%$ to variable costs (Figure 4). Within the fixed costs, the highest values were the depreciation of the machine (15.5\%) and labor cost (12.4\%). Interest costs, taxes and insurance represented $2.8 \%$.
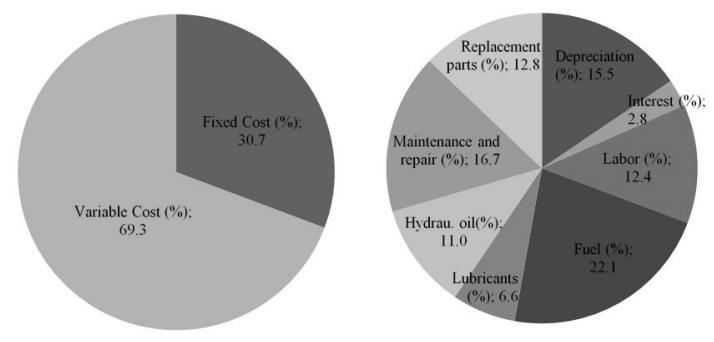

Figure 4. Distribution of the operational costs of the harvester.

Within the variable cost, fuel was the highest, with $22.1 \%$, followed by repairs and maintenance, $16.7 \%$. Also significant were the cost of parts, amounting to $12.8 \%$ of the total, hydraulic and lubricating oils, $11.0 \%$, and grease, $6.6 \%$. More than $66 \%$ of the operational cost was concentrated in depreciation, salary, fuel and repairs.

\subsection{Cost of production for the cutting and processing of trees.}

As shown in Figure 5, the result of the estimated effective productivity from the statistical model obtained above, as well as the cost of production, depended on the size of the trees. Since the production cost is obtained by relating the operational cost of the machine and the effective productivity, the tendency is for the production cost to decline as productivity increases.

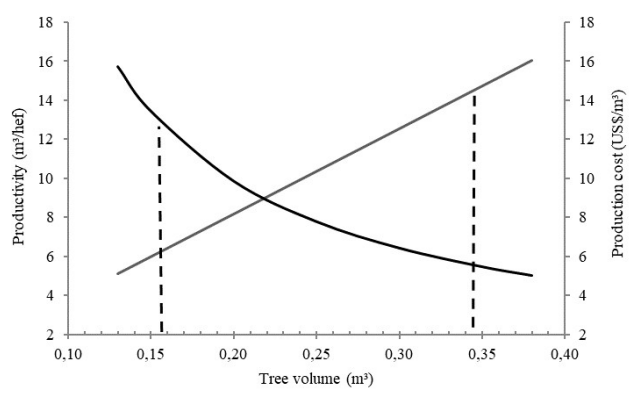

Figure 5. Productivity and production cost depending on tree volumes.

According to the information in Table 1, the average volume of trees subjected to the second thinning was $0.1648 \mathrm{~m}^{3}$ and the volume of trees of the third thinning was $0.3408 \mathrm{~m}^{3}$. The dashed line in Figure 5 shows productivity of $6.5 \mathrm{~m}^{3} / \mathrm{h}$ and production cost of approximately US $\$ 12.00 / \mathrm{m}^{3}$ for cutting and processing in the second thinning with the harvester, while for third thinning, productivity exceeded $14.0 \mathrm{~m}^{3} / \mathrm{h}$, with a production cost of less than US $\$ 6.00 / \mathrm{m}^{3}$.

Table 1. Information on the characteristics of the teak plantation subjected to thinning.

\begin{tabular}{|cccccc}
$\begin{array}{c}\text { Trees } \\
\text { (ha) }\end{array}$ & $\begin{array}{c}\text { Number } \\
\text { and age of } \\
\text { thinning }\end{array}$ & $\begin{array}{c}\text { Intensity of } \\
\text { thinning (\%) }\end{array}$ & $\begin{array}{c}\text { Trees } \\
\text { removed } \\
\text { (ha) }\end{array}$ & $\begin{array}{c}\text { DBH } \\
(\mathbf{c m})\end{array}$ & $\begin{array}{c}\text { Volume } \\
\left(\mathbf{m}^{3} / \text { tree }\right)\end{array}$ \\
\hline 1250 & 1st (6) & 40 & 500 & 12.75 & 0.0625 \\
\hline 750 & 2nd (12) & 40 & 300 & 18.46 & 0.1648 \\
\hline 450 & 3rd (18) & 45 & 202 & 24.37 & 0.3408 \\
\hline
\end{tabular}

\section{DISCUSSION}

Tolosana et al. (2002) published results on the performance of several harvesters working in Pinus sylvestris plantations for thinning with different slopes in northern Spain. The authors reported the influence of the average volume of trees extracted and the slope of the land on the productivity of the harvesters. The statistical models obtained included these two variables for the estimation of productivity. They also referred to the intensity of thinning over productivity. They suggested that for a cutting density of $25.0 \mathrm{~m}^{3} / \mathrm{ha}$, the difference in costs between an almost zero slope and another of $25.0 \%$ was greater than US $\$ 35.00 / \mathrm{m}^{3}$. For a cutting density of $150.0 \mathrm{~m}^{3} / \mathrm{ha}$, this difference did not reach US\$ $8.00 / \mathrm{m}^{3}$. 
Kärhä et al. (2004) compared two harvester groups working for Pinus sylvestris thinning, with a cutting rate of $44.0 \mathrm{~m}^{3} / \mathrm{ha}$. Four machines were used: Nokka Profi and Timberjack 770, the most expensive ones; and SampoRosenlew 1046X and Valtra Forest 120, more compact and economical. The productivity values obtained in thinning ranged between 4.0 and $12.0 \mathrm{~m}^{3} / \mathrm{h}$, very similar to the productivity obtained in this work. The authors pointed out that the cost of the first thinning was US\$ 7.50 for $14.20 / \mathrm{m}^{3}$ for the Nokka and Timberjack machines, for trees with volumes of 0.050 to $0.100 \mathrm{~m}^{3}$. The corresponding cost of the Sampo and Valtra machines was US\$ 5.70 for $10.50 / \mathrm{m}^{3}$. In the second thinning, the production cost for the first machine group was US $\$ 5.90$ for $8.50 / \mathrm{m}^{3}$ for trees with volumes of 0.100 to $0.150 \mathrm{~m}^{3}$ and the cost of the second group of machines was US $\$ 4.70$ for $6.70 / \mathrm{m}^{3}$.

Sirén and Aaltio (2013) evaluated three harvester models for the cutting and processing of Pinus sylvestris in thinned forests, cutting a volume between 42.9 to $45.2 \mathrm{~m}^{3} / \mathrm{ha}$, followed by chopping the trees into logs between 3 and 5 meters in length. The mechanical availability obtained was $84.5 \%$, the operational efficiency was $76.3 \%$, and the average productivity was $6.92 \mathrm{~m}^{3} / \mathrm{h}$. The most common interruptions involved the spindle, and especially the cutting assembly, followed by planning and contact with the supervisor, and those caused by the operator. The operational cost of the harvesters was US $\$ 50.60 / \mathrm{h}$ and the cost of production between US $\$ 5.00$ and $6.00 / \mathrm{m}^{3}$ for trees with $0.16 \mathrm{~m}^{3}$. Those findings correspond to the distribution of working time and the effective productivity obtained in this study, and the production cost increased by $50.0 \%$, influenced by the difference in the operational cost of the machine evaluated in this study of more than $38.0 \%$.

MacDonagh et al. (2013a) analyzed the performance of a John Deere 1070 D harvester combined with an H 754 head working in Pinus spp. plantations, in first thinning with 4 rows and second thinning with 7 rows, with average volumes of 0.79 and $0.76 \mathrm{~m}^{3} /$ tree. They found productivity values of $14.2 \mathrm{~m}^{3} / \mathrm{h}$ and $12.15 \mathrm{~m}^{3} / \mathrm{h}$, respectively, while for the second thinning, with an average volume of $0.354 \mathrm{~m}^{3} /$ tree, the productivity rose to $30.81 \mathrm{~m}^{3} / \mathrm{h}$. The operational cost reported by the authors was US $\$ 47.50 / \mathrm{h}$, and the production cost was less than US $\$ 5.00 / \mathrm{m}^{3}$ for cutting and processing in both thinning operations. The low production cost obtained by the authors was due to the large difference in the operational cost of the harvester studied and the high productivity of the operation, in turn influenced by the average volume of the trees.

MacDonagh et al. (2013b) evaluated a small harvester formed by a Caterpillar model 312D tractor weighing $12920 \mathrm{~kg}$, with a Log Max 5000 processor head of $924 \mathrm{~kg}$. The operation was carried for the first thinning of plantations of Pinus spp., on land with gentle slope, with average tree size of $0.128 \mathrm{~m}^{3}$ and cutting rate of $83.4 \mathrm{~m}^{3} / \mathrm{ha}$. For these conditions, productivity reached $12.99 \mathrm{~m}^{3} / \mathrm{h}$ and production cost was US $\$ 4.82 / \mathrm{m}^{3}$. These results were mainly due to differences in the operational cost of the machines and coincided with the findings of other studies conducted in Brazil by Lopes et al. (2007), of US\$ 115.72/h; Martins et al. (2009), of US\$113.28/h; and Simões et al. (2010), of US\$ 78.78/h. An exception was Silva et al. (2010), who reported a value of US $\$ 52.27 / \mathrm{h}$, using an interest rate of $6 \%$. All values exceeded the operational cost of the aforementioned authors, which explains the differences in the production cost.

Lopes et al. (2017) conducted a study to verify the effect of operational variables on the productivity of a wheeled harvester in the first thinning of Pinus taeda in the state of Paraná, Brazil. The individual volumes of the trees were 0.17 to $0.23 \mathrm{~m}^{3}$. Productivity ranged from 14.4 to $16.5 \mathrm{~m}^{3} / \mathrm{h}$ in three ranges of terrain slope, without significant differences. However, productivity values showed significant differences for the variable individual tree volume. The explanation for this fact was that most of the machine was devoted to processing the trees, causing a greater effect on productivity than slope of the land, which mainly influences the movement of the machine. The mechanical availability and operational efficiency of the harvester according to the authors were $91 \%$ and $83 \%$, respectively.

Hildt et al. (2018) published productivity estimates of a Logman $801 \mathrm{H}$ (HV 1) harvester, with tires and $4 \times 4$ traction, equipped with a KETO 150 head, for thinning plantations of Pinus taeda and Pinus elliottii in northeastern Argentina. The trees harvested in the second thinning had average volumes of $0.43 \mathrm{~m}^{3}$ for 12-year-old Pinus taeda and $0.36 \mathrm{~m}^{3}$ for 10-year-old hybrid pine, while in the third thinning, these values were $0.71 \mathrm{~m}^{3}$ for Pinus taeda aged 13 years and $0.75 \mathrm{~m}^{3}$ for hybrid pine aged 15 years, respectively. The productivity values ranged from 34.6 to $44.7 \mathrm{~m}^{3} / \mathrm{h}$, higher than those registered by other authors, explained by the higher volume of trees compared to the average volume presented in other studies.

\section{CONCLUSIONS}

Based on the results, we can conclude:

- The values of mechanical availability, operational efficiency and productivity were close to the results of several other studies of the cutting and processing of trees for thinning, although there was dispersion of the values of effective productivity when the size of the trees increased due to the trunk characteristics of the species studied. 
- The average volume of trees was strongly correlated with the productivity of cutting and harvester processing, which justifies its use as an appropriate variable in statistical models to estimate the productive performance of the machine.

- The trend of the increase in the cost of production in the cutting and processing of trees in proportion to the increase in the average volume of trees to be extracted was confirmed, and the values obtained agreed with those of several other researchers, with some divergences caused mainly by differences in operating costs of machines.

\section{SUBMISSION STATUS}

Received: 20 Jan. 2020.

Accepted: 26 Oct. 2020.

Associate editor: Vanessa Maria Basso (D)

\section{CORRESPONDENCE TO}

\section{Rafael Rodolfo Melo}

Universidade Federal Rural do Semi-Árido, Departamento de Ciências Agronômicas e Florestais, Avenida Francisco Mota, 572, CEP 59625-900, Mossoró, RN, Brasil.

e-mail: rafael.melo@ufersa.edu.br

\section{REFERENCES}

Ackerman P, Martin C, Brewer J, Ackerman, S. Effect of slope on productivity and cost of Eucalyptus pulpwood harvesting using single-grip purpose-built and excavator-based harvesters. International Journal of Forest Engineering 2018; 29(2): 74-82. https://doi.org/10.1080/14942119.2018.1431491.

Barnes RM. Motion and time study: design and measurement of work. 6.ed. New York: John Willey and Sons; 1968.

Bezerra AF, Milagres FR, Silva MLD, Leite HG. Economic analysis of settlements of Tectona grandis submitted to thinning in Mato Grosso. Cerne 2011; 17(4): 583-592. http://dx.doi.org/10.1590/ S0104-77602011000400018.

Bramucci M, Seixas F. Determinação e quantificação de fatores de influência sobre a produtividade de "harvesters" na colheita florestal. Scientia Forestalis 2002, 62(2): 62-74.

Costa EM, Marzano FLC, Machado CC, Leite ES. Desempenho e custos operacionais de um harvester em floresta de baixa produtividade. Revista Engenharia na Agricultura 2017; 25(2), 124-131. https://doi.org/10.13083/reveng.v25i2.751.

Diniz CCC, Robert RCG, Vargas MB. Avaliação técnica de cabeçotes individual e múltiplo no processamento de madeira. Advances in Forestry Science 2018; 5(1): 253-258. http://dx.doi.org/10.34062/ afs.v5i1.5523.

Fernandes HC, Burla ER, Leite ES, Minette LJ. Technical and economic evaluation of a harvester under different terrain and forest productivity conditions. Scientia Forestalis 2013; 41(97): 145-151.
Gerasimov Y, Senkin V, Väätäinen K. Productivity of single-grip harvesters in clear-cutting operations in the northern European part of Russia. European Journal of Forest Research 2012; 131(3): 647-654. http://dx.doi.org/10.1007/s10342-011-0538-9.

Hildt E, Mac Donagh MP, Somma FF, Alegranza D, Durán D. Productividad de un harvester en raleos de plantaciones de pinos en el noreste argentino. Ciência Florestal 2018; 28(4): 1627-1639. http://dx.doi.org/10.5902/1980509835128.

Johansson J. Excavators as base machines in logging operations. Journal of Forest Engineering 1995; 7(1): 7-17. https://doi.org/ 10.1080/08435243.1995.10702674.

Kärhä K, Rönkkö E, Gumse S. Productivity and Cutting Costs of Thinning Harvesters. International Journal of Forest Engineering 2004; 15(2): 43-56. https://doi.org/10.1080/14942119.2004.10702496.

Leonello EC, Gonçalves SP, Fenner PT. Efeito do tempo de experiência de operadores de Harvester no rendimento operacional. Revista Árvore 2012; 36(6): 1129-1133. http://dx.doi.org/10.1590/ S0100-67622012000600013.

Lopes ES, Cruziniani E, Dias NA, Fiedler NC. Avaliação técnica e econômica do corte de madeira de pinus com cabeçote harvester em diferentes condições operacionais. Floresta 2007; 37(3): 305-313. http://dx.doi.org/10.5380/rf.v37i3.9926.

Lopes ES, Oliveira FM, Roza BL. Efeito de variáveis operacionais na produtividade de um harvester de pneus no desbaste de pinus. Floresta 2017, 47(4): 417-426. http://dx.doi.org/10.5380/rf.v47i4.51112.

Mac Donagh PM, Hildt E, Friedl RA, Zaderenko C, Alegranza DA. Influencia de la intensidad de raleos en la performance de un harvester de ruedas en el noreste argentino. Floresta 2013a; 43(4): 653-662. http://dx.doi.org/10.5380/rf.v43i4.30367.

Mac Donagh PM, Mulawka J, Friedl R, Zaderenko C, Alegranza D. Productividad y costos de pequeños "harvester" con oruga, operando en plantaciones de Pinus spp. en el noreste argentino. Scientia Forestalis 2013b; 42(99): 425-434.

Martins RJ, Seixas F, Stape JL. Avaliação técnica e econômica de um harvester trabalhando em diferentes condições de espaçamento e arranjo de plantio em povoamento de eucalipto. Scientia Forestalis 2009; 37(83): 253-263.

Mc Ewan A, Magagnotti N, Spinelli R. The effects of number of stems per stool on cutting productivity in coppice Eucalyptus plantations. Silva Fennica 2016; 50(2): 1-14. http://dx.doi.org/10.14214/sf.1448.

Mederski PS. A comparison of harvesting productivity and costs in thinning operations with and without midfield. Forest Ecology and Management 2006; 224(3): 286-296. https://doi.org/10.1016/ j.foreco.2005.12.042.

Nakagawa M, Hayashi N, Narushima T. Effect of tree size on time of each work element and processing productivity using an excavatorbased single-grip harvester or processor at a landing. Journal for Forest Research 2010; 15(4): 226-233. https://doi.org/10.1007/ s10310-010-0180-2.

Norihiro J, Ackerman P, Spong B, Längin D. Productivity model for cut-to-length harvester operation in South African Eucalyptus pulpwood plantations. Croatian Journal of Forest Engineering 2018; 39(1):1-13. 
Purfürst FT, Erler J. The human influence on productivity in harvester operations. International Journal of Forest Engineering 2011;22(2): 15-22. https://doi.org/10.1080/14942119.2011.10702606.

Rodrigues CK, Lopes ES, Pereira ALN, Sampietro JA. Effect of individual tree volume on operational performance of harvester processor. Floresta 2019; 49(2): 345-352. http://dx.doi.org/10.5380/rf.v49i2.58233.

Seixas F, Batista JLF. Technical and economical comparison between wheel harvesters and excavators. Ciência Florestal 2014; 24(1): 185-191. http://dx.doi.org/10.5902/1980509813335.

Sessions J, Sessions JB. Cost control in forest harvesting and road construction. Rome: Food and Agriculture Organization of the United States; 1992. (FAO Forestry paper, No 99).

Silva EL, Minette LJ, Fernades CH, Souza PA, Anaral JE, Lacerda GE. Desempenho do harvester na colheita de eucalipto em diferentes espaçamentos e declividades. Revista Árvore 2014; 38(1): 1-8. http://dx.doi.org/10.1590/S0100-67622014000100009.

Silva NE, Machado CC, Minette JL, Souza PA, Silva LM, Jacovine AL. Avaliação técnica e econômica do corte mecanizado de pinus sp. com harvester. Revista Árvore 2010; 34(4): 745-753. http://dx.doi.org/10.1590/S0100-67622010000400019.

Simões D, Fenner PT. Influência do relevo na produtividade e custos do harvester. Scientia Forestalis 2010; 85(38): 107-114.
Sirén M, Aaltio H. Productivity and costs of thinning harvesters and harvester-forwarders. International Journal of Forest Engineering 2013; 14(1):39-48. https://doi.org/10.1080/14942119.2003.10702468.

Spencer, J. B. (1992). Slope limits for excavator based clear-fell and thinning harvesters. Technical development branch. Great Britain: Forestry Comission; 1992. (Technical Note 4/92).

Strandgard M, Mitchell R. Impact of number of stems per stool on mechanical harvesting of a Eucalyptus globulus coppiced plantation in south-west Western Australia. Southern Forests 2018; 80(2): 137-142. https://doi.org/10.2989/20702620.2017.1292448.

Takizawa F. Apresentação sobre a situação da teca em Mato Grosso. IV Encontro Brasileiro de Silvicultura 2018; Associação dos Reflorestadores de Mato Grosso -Arefloresta, Ribeirão Preto-SP, Brasil.

Tolosana E, Torrijos YA, Vignote S. Rendimientos, costes y efectos ambientales de las claras mecanizadas sobre repoblaciones de Pinus sylvestris L. en España. Forest Systems 2002; 11(1): 39-65.

Vargas I, Sánchez L, Vargas R, Serrano E, González DE. Productividad de la cosechadora forestal en plantaciones comerciales de eucalipto (Eucalyptus spp.). Revista Mexicana de Ciencias Forestales 2012; 3(12): 57-102. 